NBER WORKING PAPER SERIES

\title{
DOES MISERY LOVE COMPANY? \\ EVIDENCE FROM PHARMACEUTICAL MARKETS BEFORE AND AFTER THE ORPHAN DRUG ACT
}

\author{
Frank R. Lichtenberg \\ Joel Waldfogel \\ Working Paper 9750 \\ http://www.nber.org/papers/w9750 \\ NATIONAL BUREAU OF ECONOMIC RESEARCH \\ 1050 Massachusetts Avenue \\ Cambridge, MA 02138 \\ June 2003
}

The views expressed herein are those of the authors and not necessarily those of the National Bureau of Economic Research.

(C2003 by Frank R. Lichtenberg and Joel Waldfogel. All rights reserved. Short sections of text not to exceed two paragraphs, may be quoted without explicit permission provided that full credit including $(\mathrm{C}$ notice, is given to the source. 
Does Misery Love Company? Evidence from pharmaceutical markets before and after the Orphan Drug Act

Frank R. Lichtenberg and Joel Waldfogel

NBER Working Paper No. 9750

June 2003

JEL No. L11, I12, L65

\begin{abstract}
With substantial fixed costs of drug development, more common conditions can support more products. If additional pharmaceutical products are beneficial, they will attract greater consumption and promote better health, e.g. greater longevity. We ask how market size - measured by condition prevalence - affects consumption and longevity. We document in condition cross sections that both the tendency to use a drug and longevity are higher for individuals with more prevalent conditions. We also make use of the 1983 Orphan Drug Act (ODA), which promoted development of drugs for the treatment of rare conditions. Longevity and drug use have grown more quickly for persons with rare diseases and even more quickly for persons with conditions with substantial orphan drug use.
\end{abstract}

Frank R. Lichtenberg

Graduate School of Business

Columbia University

3022 Broadway, 726 Uris Hall

New York, NY 10027

and NBER

frank.lichtenberg@columbia.edu
Joel Waldfogel

Public Policy and Management

University of Pennsylvania

Wharton School

3100 Steinberg-Dietrich Hall

Philadelphia, PA 19104-6372

and NBER

waldfogj@wharton.upenn.edu 
When production entails fixed or sunk costs, the number of products developed can increase in the size of the market. A larger potential market provides greater reward for firms that can bring a product to market. Additional products increase welfare because if products are differentiated, then additional products confer benefits by allowing more types of consumers options that better suit their needs. In this way, consumers benefit each other via a mechanism one might term "preference externalities." Of course, whether products are differentiated or not, additional products can place downward pressure on prices. ${ }^{1}$

Although the relationship between market size and consumption and, by extension, welfare operating through product variety follows from theory in straightforward ways, evidence on it is scarce. ${ }^{2}$ Yet, the conditions giving rise to this phenomenon can appear whenever fixed costs are large relative to market size. Nowhere is this more likely to be true than in pharmaceutical markets. According to the Tufts Center for the Study of Drug Development, the average cost to develop a new molecular entity is $\$ 802$ million $^{3}$ The number of drugs available per condition bears out the claim that drug development costs are large relative to market size for many conditions. The median number of drugs labeled to treat a four-digit ICD9 condition is $2 .^{4}$ These facts lead us to ask whether individuals are better off in their capacity as drug consumers if

\footnotetext{
${ }^{1}$ These are the mechanisms outlined in seminal papers by Spence (1976a,b) and Dixit and Stiglitz (1977). See Mankiw and Whinston (1986) for a paper emphasizing possible inefficiencies of entry.

2 See Waldfogel (forthcoming) and George and Waldfogel (forthcoming).

${ }^{3}$ The Tufts study was based on detailed survey data obtained directly from 10 drug companies. A similar study done by the Tufts Center a decade ago indicated that the average cost to develop a new drug was then about \$231 million, in 1987 dollars. See http://csdd.tufts.edu/NewsEvents/RecentNews.asp?newsid=6.

${ }^{4}$ Source: Drug Indications Master Table of First DataBank's National Drug Data File.
} 
their condition is more common. More succinctly, we ask whether "misery loves company."

Despite the novelty of the academic question of the welfare of small consumer groups in markets, concern about this issue is not new to policy makers. The possibility that small populations would see few medications developed for their conditions led the US Congress to pass the 1983 Orphan Drug Act (ODA), giving firms special incentives to develop drugs for diseases afflicting fewer than 200,000 Americans. ${ }^{5}$ The ODA contains provisions that reduce the cost, and raise the appropriability, of research on rare diseases. First, under the Act drugs approved as orphan drugs (for conditions affecting fewer than 200,000 persons), drug makers get seven years of exclusive marketing upon FDA approval. According to the FDA, this is the "most sought incentive." For seven years following FDA approval, the FDA cannot approve another drug for the same indication without the sponsor's consent. Second, drug makers qualify for a tax credit for clinical research expense of up to 50 percent of clinical testing expense (see http://www.fda.gov/orphan/taxcred.htm). In addition the FDA provides grant support for investigation of rare disease treatments (see http://www.fda.gov/orphan/grants/info.htm). Together, these provisions a) increase effective market size, and b) reduced fixed (sunk) costs. In doing so, the Act provides a natural experiment for measuring the impact of increased market size, relative to fixed costs, on product development, consumption, and welfare.

According to the FDA, the ODA has had a large effect on drug development:“'ODA has been very successful - more than 200 drugs and biological products for rare diseases have been brought to market since 1983. In contrast, the

\footnotetext{
${ }^{5}$ See http://www.fda.gov/orphan/oda.htm
} 
decade prior to 1983 saw fewer than ten such products come to market. ${ }^{16}$ A complete list of the drugs that have been granted Orphan Drug Status by the FDA is provided in Appendix Table $1 .^{7}$ Figure 1 shows the cumulative number of orphan and non-orphan drugs approved, 1979-1998, as a percent of the cumulative number of drugs approved in 1979.

Figure 1

Cumulative number of drugs approved, as \% of cumulative number of drugs approved in 1979: orphan vs. other drugs

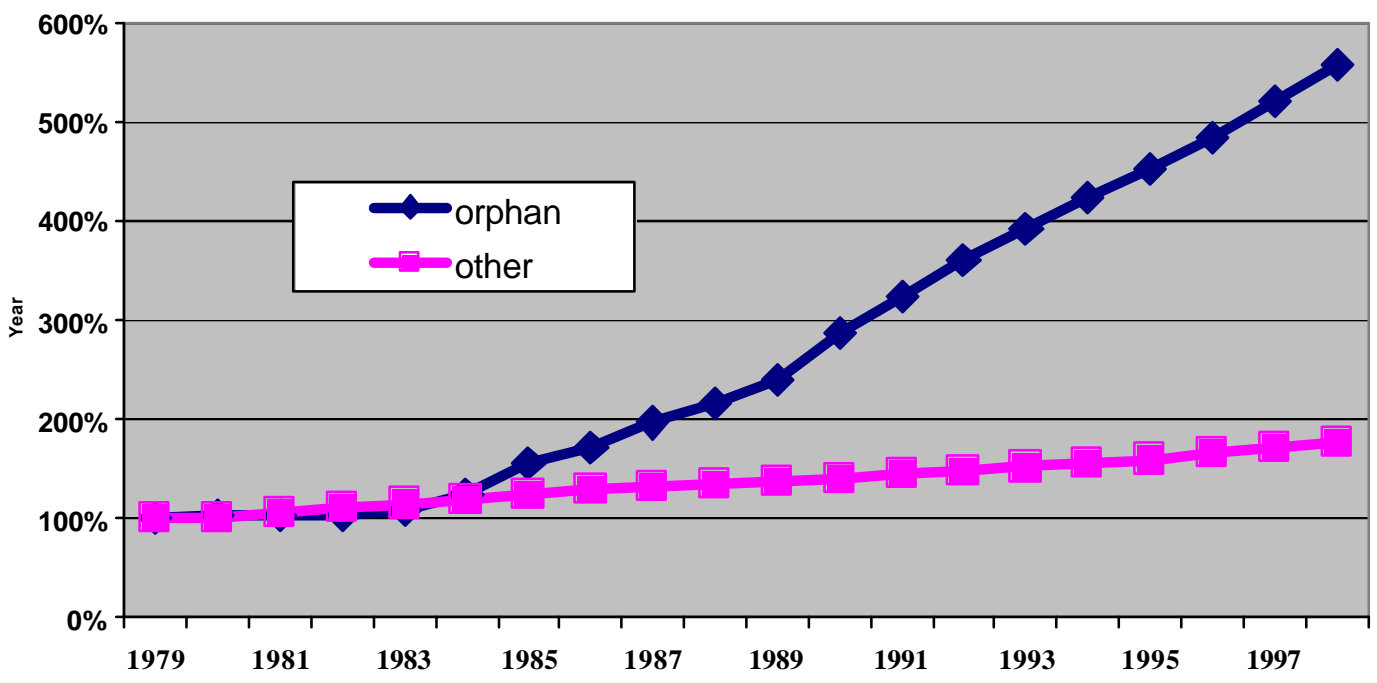

Between 1979 and 1983, the number of orphan drugs increased at about the same rate as the number of other drugs. By 1998, there were more than five times as many orphan drugs as there had been in 1979, and fewer than twice as many non-orphan drugs.

In light of the apparent effect of the ODA on drug development, we examine its effect on two measures related to welfare, consumption and mortality. First, we ask whether there is evidence, in the pharmaceutical context, that misery loves company. We compare across conditions with different levels of prevalence ("market size"), asking

\footnotetext{
${ }^{6}$ Source: http://www.fda.gov/orphan/History.htm.

${ }^{7}$ Some of these drugs also have non-orphan indications, i.e. they may be used to treat common diseases.
} 
whether physicians are more likely to prescribe drugs for common diseases, and whether people with common diseases are likely to live longer. Results from this approach are highly suggestive: more prevalent conditions have substantially more products available, and we document both that larger affected populations are much more likely to take a drug and that mortality rates are lower for persons with more common conditions. A shortcoming of this approach, however, is the possibility of unobserved heterogeneity leading both to large markets and many drugs. Putting this differently, the cross sectional measurement strategy may not provide a clean source of exogenous variation in market size.

Conveniently, the passage of the Orphan Drug Act provides a source of exogenous variation in market size, relative to fixed costs, for drugs targeting small populations. This motivates our second measurement approach for documenting the effect of market size on drug consumption and, by extension, welfare. We document growth in consumption and increases in longevity for individuals with less common conditions, relative to those with more common conditions. Moreover, we document that these effects on consumption and longevity are significantly related to Orphan Drug use for the condition.

The paper proceeds in four sections. Section 1 provides background by outlining the mechanism for preference externalities. We also review relevant literature. Section 2 describes the data used in this study. Section 3 presents our empirical strategy and results. We find clear cross sectional evidence that misery loves company, both before and after the Orphan Drug Law. But the Law appears to have weakened the link between market size and welfare. Conditions with substantial Orphan Drug use have larger 
increases in consumption and longevity than others. In the conclusion we consider our results in both narrow and broad contexts.

\section{Market Size, Entry, and Welfare: Why Would Misery Love Company?}

This paper is mainly concerned with the positive question of how market size affects drug development, consumption, and other measures of welfare. Still, it is helpful to locate this problem in its normative context, which we briefly do below.

When development carries sunk costs and products are imperfect substitutes, markets can fail to achieve optimal outcomes. ${ }^{8}$ First, if sellers cannot appropriate the entire consumer valuation of their product, some products with consumer valuation in excess of their production cost will not be developed. That is, inefficient under-provision is possible. At the same time, because products are substitutes, the private benefit of entry can exceed the social benefit if some of a produc t's business is diverted from other products. ${ }^{9}$ For illustration, consider an additional identical product. It imposes its fixed cost on society, but adds no consumer benefit (except, possibly, reduced prices). It is possible, as a result, for markets to support inefficient overprovision of products with sufficient total demand to cover the costs of multiple products. Spence terms the process by which the market determines what to produce, "the product selection problem."

Some products that the market selects not to produce are candidates for the "inefficient underprovision" designation. Indeed, one can view the ODA as an attempt to

\footnotetext{
${ }^{8}$ These problems are the subject of important theoretical papers by Spence $(1976 \mathrm{a}, \mathrm{b})$ and Dixit and Stiglitz (1977).

${ }^{9}$ Lichtenberg and Philipson (2003) provide evidence that the present discounted value of a pharmaceutical innovator's returns is reduced more by competition from other brands ("creative destruction") prior to patent expiration than it is by competition from generic manufacturers after patent expiration.
} 
remedy inefficient underprovision. In this case, the reason the allocation may be inefficient is presumably inability to price discriminate.

We envision firms introducing competing products as long as it is profitable to do so. Competing products are imperfect substitutes for one another. Different products in a category work best for different sorts of patients, so that additional products in a category may draw additional persons to consumption. A sufficient, although not necessary, condition for additional products to increase welfare is that additional products raise the tendency for patients to consume a drug in the category corresponding to their condition. We assume that drug development carries only fixed (sunk) costs. The presence of more products creates greater potential for consumers to find a product closer to their ideal. Unless pricing extracts all surplus, consumer welfare is greater. ${ }^{10}$

The "business stealing vs. market expansion" distinction provides a helpful framework for viewing the relationship between consumption and welfare (see Mankiw and Whinston, 1986). If a new drug is substantially differentiated, it may draw new customers into the market rather than simply diverting business from existing products. In this case, the share of affected people consuming a drug will increase with entry. On the other hand, an undifferentiated product may draw all of its business from existing products and will therefore not increase the tendency to consume. Of course, additional

\footnotetext{
${ }^{10}$ We recognize that a higher tendency to consume in a cross section does not necessarily reflect higher welfare. Welfare is not higher if 80 percent of people are barely willing to consume than if 79 percent of persons consume and derive substantial surplus. On the other hand, if the arrival of a new product (without withdrawal of existing products) raises the tendency to consume, then by revealed preference welfare is higher. We will treat consumption tendencies as suggestive evidence about welfare in the paper, paying particular attention to results from longitudinal measurement approaches.
} 
products can put downward pressure on prices, and this pressure is presumably more acute as the products are less differentiated. ${ }^{11}$

In this scheme it is easy to see how misery loves company. An increase in market size raises the amount of revenue available to a product category, possibly justifying the development of an additional product. An additional product may attract a new customer (valuing the product above its price), whose use of the product generates some combination of consumer surplus and greater longevity. Furthermore, additional products may reduce the price paid by all customers.

The passage of the ODA increases the effective size of the market, relative to fixed costs, for drugs targeting uncommon conditions. This may give rise to more products in those categories, as well as a greater tendency to consume. Because rare conditions are targeted by few products, especially prior to the ODA, new products spurred by the ODA are likely to be strongly differentiated products; that is, their entry provides some product, as opposed to no product.

The foregoing suggests the following questions. Do larger markets attract more products? Is there a greater tendency to consume in markets with more products and/or lower prices? Do additional products promote longevity? We now turn to the empirical analysis of these questions.

\section{Data}

The basic data for this study are information on disease prevalence, prescription drug consumption, and longevity, by 3-digit ICD-9 disease code, in 1979 and 1998. These observations occur before and fairly long after the 1983 ODA. In addition, we

\footnotetext{
${ }^{11}$ This is the mechanism documented indirectly, based on the relationship between market size and entry, by Bresnahan and Reiss $(1990,1991)$.
} 
have information on the fraction of prescriptions written for orphan drugs between 1995 and 2000. Our data are drawn from two sources, which we describe below.

\section{Physician Survey Data on Drug Consumption and Condition Prevalence}

Our primary data on drug consumption and prevalence are drawn from a physician survey, the National Ambulatory Medical Care Surveys (NAMCS). The NAMCS surveys offer information on patients' visits to a national sample of office-based physicians. The universe consists of office visits to nonfederally employed physicians classified by the American Medical Association (AMA) or the American Osteopathic Association (AOA) as "office-based, patient care" (excluding specialties of anesthesiology, pathology, and radiology), from 112 Primary Sampling Units (PSUs) in the United States.

Each NAMCS office visit record reports the physician's diagnoses (usually only one), any drugs ordered, administered, or provided, and a sampling weight. We measure condition i's prevalence in a year based on the number of visits with primary diagnosis $i$. In particular, we define:

N_VISIT_PRE $=$ the estimated annual number of office-based physician visits in which 3-digit ICD9 diagnosis i was recorded in the pre-ODA period (1980$1981)^{12} ;$ and

N_VISIT_POST $\mathrm{i}_{\mathrm{i}}=$ the estimated annual number of office-based physician visits in which 3-digit ICD9 diagnosis i was recorded in the post-ODA period (19971998).

\footnotetext{
${ }^{12}$ NAMCS was conducted in 1980, 1981, 1985, and annually since 1989.
} 
Thus, the NAMCS-based prevalence measure is based only on physician visits. The advantage of this sampling condition is that physician diagnoses are more likely than self-diagnoses to be correct. At the same time, this sampling has the possible disadvantage of excluding persons who are ill but do not seek medical care.

We measure drug consumption tendencies from prescription information in the NAMCS in two ways. Our first measure is whether patients diagnosed with a condition have one or more drugs prescribed for them. The "consumption" measure is therefore based not literally on consumption but rather whether the doctor believes beneficial drugs exist for the individual's circumstance. In particular, the fraction of visits with primary diagnosis $\mathrm{i}$ in which one or more drugs were prescribed as follows:

$\mathrm{RX} \% \mathrm{PRE}_{\mathrm{i}}=$ visits in which any medications were prescribed as a fraction of total visits in which 3-digit ICD9 diagnosis i was recorded in the pre-ODA period (1980-1981); and

$\mathrm{RX} \% \_\mathrm{POST}_{\mathrm{i}}=$ visits in which any medications were prescribed as a fraction of total visits in which 3-digit ICD9 diagnosis i was recorded in the post-ODA period (1997-1998).

Our second consumption measure is the average number of drugs prescribed per visit, by condition.

\section{Longevity and Prevalence Data from Vital Statistics}

Our data on longevity, as well as a second measure of prevalence, are drawn from Vital Statistics-Mortality Detail files. Two items that are recorded on death certificates are the cause of death, and the age at death. The number of (non-infant) deaths due to a 
condition is our second measure of prevalence. We measure longevity using the percent of people dying before age 55 (excluding infant deaths) due to a condition.

\section{Orphan Drug Use}

The third piece of information for this study is a measure of Orphan Drug use. We use the percent of 1995-2000 prescriptions, by 3-digit ICD-9 condition, that are for the Orphan Drugs listed in Appendix Table 1. These data are drawn from NAMCS.

Table 1 provides summary statistics on prevalence and consumption measures from the NAMCS survey and the Vital Statistics mortality data. We restrict attention to the 479 3-digit ICD-9 codes for which all variables are available. The first two columns report unweighted means, while the latter two columns report means weighted by contemporaneous MD visit prevalence measures. All measures of prevalence increase over time as do all of the measures of drug consumption. The share of deaths occurring young declines over time in both weighted and unweighted measures. We do not observe orphan drug use for the early period, although we can safely assume it is close to zero. By contrast, roughly 5 percent of prescriptions written between 1995 and 2000 are for Orphan drugs. The median is 3.3 percent, while the $25^{\text {th }}$ and $75^{\text {th }}$ percentiles of the distribution are 0.3 and 8.1 percent, respectively.

\section{Empirical Strategy and Results}

\section{Empirical Strategy}


Our goal in this paper is to measure the effect of market size on consumer welfare in drug markets, and we employ two empirical strategies. First, we exploit cross sectional comparisons across conditions with different levels of prevalence ("market size"), asking whether physicians are more likely to prescribe drugs to patients with more prevalent conditions. The inherent difficulty with this approach, however, is the possibility of unobserved heterogeneity leading both to large markets and many drugs.

Fortunately, the passage of the Orphan Drug Act provides a source of exogenous variation in market size for drugs targeting small populations. Using panel data at two points in time, along with a measure of Orphan Drug use, we can exploit this policy change to provide more compelling evidence of the effects of market size on consumption and mortality, than one might find using cross-sectional comparisons across medical conditions alone. As a useful byproduct of this approach, we can also simply examine the effectiveness of the Orphan Drug Act.

\section{Prevalence and Consumption using Physician Survey Data}

Do persons with more common conditions have a greater tendency to take a drug? First, we estimate cross-condition relationships between the tendency to take a drug and condition prevalence, via the following equations:

$R X \% \_P R E_{i}=\alpha_{0}+\beta_{0} \ln \left(N_{-}\right.$VISIT_PRE $)+\varepsilon_{i 0}$

$\mathrm{RX} \% \_\mathrm{POST}_{\mathrm{i}}=\alpha_{1}+\beta_{1} \ln \left(\mathrm{N} \_\mathrm{VISIT} \_\mathrm{POST} \mathrm{T}_{\mathrm{i}}\right)+\varepsilon_{\mathrm{i} 1}$

where eq. (1) characterizes the pre-ODA period and eq. (2) characterizes this relationship in the post-ODA period. We recognize that these are very parsimonious specifications of what are, essentially, demand equations. It would be natural to also include a drug price 
as an explanatory variable. We experimented with a number of price measures and found little sensitivity of consumption to prices, perhaps owing to the role of insurance in financing prescription drug expenditures. We also include specifications using the mortality-based prevalence measure, as well as both measures. All regressions are weighted by the contemporaneous MD visit prevalence measure.

The estimates are reported in table 2. Consistent with our expectations, probability of drug use is higher for more prevalent diseases both before and after enactment of the ODA in all specifications. That is, misery loves company, in the sense that persons with more prevalent conditions are more likely to find a suitable prescription drug. The dependence of drug use on the MD visit prevalence measure declines after the ODA. Using the pre-ODA estimates in the first column, 45 percent of persons with a condition in the $25^{\text {th }}$ percentile of prevalence would take a drug compared with 62 percent of persons with a condition in the $75^{\text {th }}$ prevalence percentile. By contrast, the column 4 post-ODA estimates indicate that 45 percent of persons in the $25^{\text {th }}$ prevalence percentile get a prescription compared with 59 percent in the $75^{\text {th }}$ percentile.

It is possible that the cross sectional relationship between consumption and prevalence arises because of unobserved heterogeneity. Some factor determining consumption may be correlated with prevalence for reasons outside our explanation. ${ }^{13}$ Because we have consumption data at two points in time, we can eliminate the fixed unobservable by differencing. We can then test whether the change in consumption is larger for the conditions for which patients take orphan drugs. It is also possible that

\footnotetext{
${ }^{13}$ For example, the measure of prevalence used in these regressions, doctor visits where a condition is diagnosed, may be driven by the known availability of particular medications (e.g. Viagra). Other measurement approaches we employ, including both longitudinal data and mortality-based prevalence measures, avoid these problems. Death is not endogenous in the same way as doctor visits.
} 
drug consumption is growing at different rates for conditions with different levels of prevalence. To avoid attributing a general prevalence effect to Orphan drug use we also include measures of condition prevalence in the regressions as follows:

$$
\Delta \mathrm{RX} \%_{\mathrm{i}}=\alpha_{\Delta}+\beta_{\Delta} \ln \left(\mathrm{N}_{-} \text {VISIT_PRE }\right)+\gamma_{\Delta}\left(\% \text { orphan }_{\mathrm{i}}\right)+\varepsilon_{\mathrm{i} \Delta}
$$

where

$$
\Delta \mathrm{RX} \%_{\mathrm{i}}=\mathrm{RX} \% \mathrm{POST}_{\mathrm{i}}-\mathrm{RX} \% \mathrm{PRE}_{\mathrm{i}}
$$

Finally, we include regressions controlling for prevalence with dummies for prevalence quintiles according to $1979 \mathrm{MD}$ visits. Table 3 reports results of these regressions. The change in the tendency to have a drug prescribed bears a positive and generally significant relationship to the orphan drug measure. This relationship survives the inclusion of controls for condition prevalence. The range of point estimates falls between 0.16 and 0.3. Between 1979 and 1998 the tendency to have some drug prescribed increases from 71 to 73 percent. At the mean level of orphan drug use (about 5 percent), orphan drugs raise the tendency to have a drug by between 0.8 and 1.5 percentage points beyond the baseline increase with time. At the $90^{\text {th }}$ percentile of orphan drug use (16 percent), the effect is between 2.5 and 5 percentage points. The orphan effects on whether one has a drug prescribed are large relative to the overall increase in this measure.

Tables 4 and 5 revisit the relationships in table 2 and 3 with a different measure of consumption, the number of drugs prescribed rather than the tendency to have any prescriptions. In table 4, as in table 2 , drug use increases in market size. Using this measure of consumption, misery loves company. In contrast with the consumption results based on the share consuming, here the dependence of consumption on market size is higher after the ODA than before. 
Similarly, in table 5 as in table 3 , the number of drugs prescribed increases more quickly as our orphan drug measure is higher. The mean number of drugs taken increases by 0.26 between 1979 and 1998 (see table 1). At the mean of orphan drug use (0.05) the orphan effect adds between 0.02 and 0.05 to the baseline increase in drugs taken; at the $90^{\text {th }}$ percentile or orphan drug use, the effect is between 0.06 and 0.17 . In contrast with results on whether one takes a drug, the orphan effects on number of drugs taken are small.

\section{Mortality and Prevalence}

Although product consumption is the usual economic measure underlying welfare inferences, the medical context provides other intuitive measures of welfare. We can use the Vital Statistics to examine the relationship between prevalence and longevity, as measured by the percent of persons, among those dying of a condition, dying before age 55. Our empirical approaches are analogous to those above.

Table 6 shows cross sectional regressions of our longevity measure on the prevalence measures. In all cases conditions that are more prevalent have lower fractions of their deaths occurring young. A disease at the $25^{\text {th }}$ prevalence percentile (by MD visits) in 1979 has 21 percent of its deaths occurring young, compared with 13 percent young for conditions in the $75^{\text {th }}$ prevalence percentile. In 1998, the percent of deaths occurring young for conditions at the $25^{\text {th }}$ prevalence percentile had fallen by 6 points to 16 percent, while the percent of deaths occurring young for more common conditions - in the $75^{\text {th }}$ percentile - had fallen only two percentage points, to 11 percent. Both before and after the ODA, misery loves company in the sense that more prevalent conditions 
have greater longevity. Furthermore, the dependence of longevity on prevalence declines following the ODA.

Finally, table 7 shows that the change over time in longevity is larger - the percent dying young declines more - for conditions with more orphan drug consumption. ${ }^{14}$ Overall the percent dying before 55 falls by 6.7 percentage points (from 25.6 to 18.9). For a disease with the mean orphan drug use the additional orphan-related decline is 0.2 to 0.4 percentage points; for a condition at the $90^{\text {th }}$ percentile of orphan drug use, the additional decline is 0.8 to 1.3 percentage points.

\section{Discussion: the ODA's Effects and Context}

The effects of the ODA are visible in a variety of ways in our results. Prior to the ODA, drug availability - and ensuing welfare - were more sensitive to market size. We see this primarily in the contrast between the pre and post-ODA estimates of the relationship between share consuming and prevalence. The ODA increased the incentive for firms to develop drugs for small populations, relative to the incentive for larger populations. As a result, there was sharper growth in the drug consumption tendency in low-prevalence conditions than in more common conditions. Similarly, there was a large decrease in mortality for low-prevalence conditions relative to higher-prevalence conditions. The ODA decreased the extent to which misery loves company. It is not clear whether these effects are efficient, although if the Act simply allows more complete appropriation of drug benefits, then there would be no reason to suspect inefficiency.

\footnotetext{
${ }^{14}$ This is consistent with evidence presented in Lichtenberg (2003) that, in general, medical conditions with greater increases in the number of drugs available exhibit greater increases in longevity (mean age at death).
} 
Most observers of the ODA applaud this policy precisely for its effect of reducing the dependence of welfare on market size. Intuitively, in the context of disease, it is not hard to understand the popularity of this policy. Yet, the conditions facing would-be consumers of drugs for unpopular conditions are not unique to pharmaceutical markets. These conditions arise, generically, whenever there are large fixed costs and preferences that differ across consumers.

The process by which markets select which products to make causes markets to deliver more welfare to persons with common preferences than to persons with uncommon ones. As Spence (1977) has emphasized, there is no reason to expect the market to select the right mix of products in contexts of this sort. As we consider the sense of the ODA, we might also ask whether other policies aimed at raising the welfare of small consumer groups are also justified.

Some people believe that investment is not too sensitive to incentives (e.g. patent enforcement, price controls). They doubt that weakening patent protection or imposing price controls would significantly reduce investment in new drug development. ${ }^{15}$ Our evidence supports the hypothesis that at least one type of incentive (the extent of the market) has an important effect on the amount of investment. It may shed light on the effect of changes in other incentives on investment. For example, a government-

15 See, for example, "Would Lower Prescription Drug Prices Curb Drug Company Research \& Development?" at the Public Citizen website (http://www.citizen.org/congress/reform/drug_industry/profits/articles.cfm?ID=7909, accesed 4/8/2003). 
mandated $25 \%$ price reduction may have a similar effect on investment as a ("marketmandated") $25 \%$ reduction in prevalence. 


\section{Conclusion}

The results show two things. First, the results show that in this market, as in some others, supply-side nonconvexities give rise to an important relationship between market size and consumption and, arguably, welfare. In this context, misery loves company. This has broad implications. First, market size matters in provid ing incentives for product development.

Second, the prevailing, and generally implicit, view is that market allocation, unlike allocation through collective choice, gives each consumer whatever she wants, regardless of her fellow consumers' preferences. Given the large drug development costs, however, consumers see drugs developed for their conditions only as they make up large potential markets. Our results are, frankly, not surprising; but they do provide some evidence about how the mix of differentiated products selected in a market depends on the distribution of product-preferring types in the market.

Third, our results show that the Orphan Drug Law "works," in the sense that it has induced increased development of drugs targeted at small populations and that these populations are now more likely to take drugs. The policy is lauded, and other policies of this type (equalizing utility across large and small populations) exist. Perhaps most notably, the U.S. Postal Service has an explicit policy of charging the same rates for postage regardless of letter origin or destination within the U.S. If mail pricing were left entirely to the market, postage rates would presumably be lower for letters sent to and from densely populated areas. Under government provision, by contrast, administered rates are the same for consumers with substantially different costs of service, in densely and sparsely populated areas. 
It is becoming increasingly clear that in large-fixed cost contexts where preferences differ across individuals, markets deliver fewer products and perhaps less satisfaction to small groups. In the pharmaceutical market this is deemed a bad feature of market outcomes; and policies have been devised to remedy the situation. Yet, there is no clear distinction between the economic circumstances of pharmaceutical markets and other large-fixed-cost markets. How widely such a policy rationale should be applied is an important remaining question for policymakers. 


\section{References}

Berry, Steven T. and Joel Waldfogel. "Free Entry and Social Inefficiency in Radio Broadcasting." RAND Journal of Economics. 1999.

Bresnahan, Timothy F; Reiss, Peter C. "Entry and Competition in Concentrated Markets.” Journal of Political Economy. Vol. 99 (5). p 977-1009. October 1991.

Bresnahan, Timothy F; Reiss, Peter C. "Entry in Monopoly Markets." The Review of Economic Studies. Vol. 57 (4). p 531-53. October 1990.

Dixit, Avinash K; Stiglitz, Joseph E. "Monopolistic Competition and Optimum Product Diversity." American Economic Review. Vol. 67 (3). p 297-308. June 1977.

George, Lisa and Joel Waldfogel. "Who Affects Whom in Daily Newspaper Markets?", forthcoming, Journal of Political Economy

Lichtenberg, Frank (2003), "Pharmaceutical Knowledge-Capital Accumulation and Longevity," in Measuring Capital in the New Economy, ed. by Carol Corrado, John Haltiwanger, and Dan Sichel, (University of Chicago Press, forthcoming).

Lichtenberg, Frank, and Tomas Philipson (2003), “The Dual Effects of Intellectual Property Regulations: Within- and Between-Patent Competition in the U.S. Pharmaceuticals Industry," Journal of Law and Economics, forthcoming.

Mankiw, N Gregory; Whinston, Michael D. Free Entry and Social Inefficiency. Rand Journal of Economics. Vol. 17 (1). p 48-58. Spring 1986.

Spence, Michael. "Product Selection, Fixed Costs, and Monopolistic Competition." The Review of Economic Studies. Vol. 43 (2). p 217-35. June 1976.

Spence, Michael. "Product Differentiation and Welfare." American Economic Review. Vol. 66 (2). p 407-14. May 1976.

Waldfogel, Joel. "Preference Externalities: An Empirical Study of Who Benefits Whom in Differentiated Product Markets" forthcoming, RAND Journal of Economics 
Table 1: Summary Statistics

\begin{tabular}{|l|r|r|r|r|}
\hline & \multicolumn{2}{|c|}{ Unweighted } & \multicolumn{2}{c|}{ Weighted } \\
\hline & $\begin{array}{c}\text { Pre-ODA } \\
(1978)\end{array}$ & $\begin{array}{c}\text { Post-ODA } \\
(1998)\end{array}$ & $\begin{array}{c}\text { Pre-ODA } \\
(1978)\end{array}$ & $\begin{array}{c}\text { Post-ODA } \\
(1998)\end{array}$ \\
\hline MD Visits (mil) & 0.76 & 1.04 & 5.69 & 7.16 \\
\hline Deaths & 3601.34 & 4478.90 & 8551.9 & 11087.7 \\
\hline \% Dying Young & $31.23 \%$ & $27.60 \%$ & $25.59 \%$ & $18.87 \%$ \\
\hline Share w/ Rx & 0.59 & 0.64 & 0.71 & 0.73 \\
\hline Mean Rx's & 1.16 & 1.51 & 1.40 & 1.66 \\
\hline Orphan \% of Rx ('95-2000) & & $5.94 \%$ & & $4.45 \%$ \\
\hline N (3-digit ICD-9 codes) & 479 & 479 & 479 & 479 \\
\hline
\end{tabular}

Notes: weighted means are weighted by contemporaneous MD visits. 
Table 2: Share Consuming a Drug and Prevalence.

\begin{tabular}{|c|c|c|c|c|c|c|}
\hline & (1) & $(2)$ & (3) & (4) & $(5)$ & $(6)$ \\
\hline & $\begin{array}{c}\text { Share Getting Rx } \\
\text { Pre }\end{array}$ & $\begin{array}{c}\text { Share Getting Rx } \\
\text { Pre }\end{array}$ & $\begin{array}{c}\text { Share Getting Rx } \\
\text { Pre }\end{array}$ & $\begin{array}{c}\text { Share Getting Rx } \\
\text { Post }\end{array}$ & $\begin{array}{c}\text { Share Getting Rx } \\
\text { Post }\end{array}$ & $\begin{array}{c}\text { Share Getting Rx } \\
\text { Post }\end{array}$ \\
\hline Log MD Visits (pre) & $\begin{array}{c}0.0657 \\
(0.0063)^{* *}\end{array}$ & & $\begin{array}{c}0.0638 \\
(0.0060)^{* *}\end{array}$ & & & \\
\hline Log Deaths '79 & & $\begin{array}{c}0.0176 \\
(0.0033)^{* *}\end{array}$ & $\begin{array}{c}0.0079 \\
(0.0030)^{* *}\end{array}$ & & & \\
\hline Log MD Visits (post) & & & & $\begin{array}{c}0.0573 \\
(0.0051)^{* *}\end{array}$ & & $\begin{array}{c}0.0537 \\
(0.0052)^{* *}\end{array}$ \\
\hline Log Deaths '98 & & & & & $\begin{array}{c}0.0127 \\
(0.0024)^{* *}\end{array}$ & $\begin{array}{c}0.0083 \\
(0.0022)^{* *}\end{array}$ \\
\hline Constant & $\begin{array}{c}-0.2570 \\
(0.0940)^{* *}\end{array}$ & $\begin{array}{c}0.8630 \\
(0.0296)^{* *}\end{array}$ & $\begin{array}{l}-0.1591 \\
(0.0971)\end{array}$ & $\begin{array}{l}-0.1406 \\
(0.0782)\end{array}$ & $\begin{array}{c}0.8288 \\
(0.0212)^{* *}\end{array}$ & $\begin{array}{l}-0.0182 \\
(0.0839)\end{array}$ \\
\hline Observations & 479 & 479 & 479 & 479 & 479 & 479 \\
\hline R-squared & 0.18 & 0.06 & 0.22 & 0.21 & 0.05 & 0.23 \\
\hline
\end{tabular}

Notes: Standard errors in parentheses. * significant at 5\%;** significant at $1 \%$. All regressions weighted by contemporaneous MD visits. 
Table 3: Change in Share Consuming a Drug, Prevalence, and Orphan Drug Use

\begin{tabular}{|c|c|c|c|c|c|c|c|c|}
\hline & (1) & (2) & (3) & (4) & $(5)$ & (6) & (7) & (8) \\
\hline & $\begin{array}{l}\text { Change in } \\
\text { Share } \\
\text { Consuming } \\
\text { Rx }\end{array}$ & $\begin{array}{c}\text { Change in } \\
\text { Share } \\
\text { Consuming } \\
\text { Rx }\end{array}$ & $\begin{array}{c}\text { Change in } \\
\text { Share } \\
\text { Consuming } \\
\text { Rx }\end{array}$ & $\begin{array}{c}\text { Change in } \\
\text { Share } \\
\text { Consuming } \\
\text { Rx }\end{array}$ & $\begin{array}{c}\text { Change in } \\
\text { Share } \\
\text { Consuming } \\
\text { Rx }\end{array}$ & $\begin{array}{c}\text { Change in } \\
\text { Share } \\
\text { Consuming } \\
\text { Rx }\end{array}$ & $\begin{array}{c}\text { Change in } \\
\text { Share } \\
\text { Consuming } \\
\text { Rx }\end{array}$ & $\begin{array}{c}\text { Change in } \\
\text { Share } \\
\text { Consuming } \\
\text { Rx }\end{array}$ \\
\hline Log MD Visits (pre) & $\begin{array}{c}-0.0172 \\
(0.0034) * *\end{array}$ & & & $\begin{array}{c}-0.0156 \\
(0.0036)^{* *}\end{array}$ & & $\begin{array}{c}-0.0158 \\
(0.0037)^{* *}\end{array}$ & & \\
\hline Log Deaths '79 & & $\begin{array}{l}-0.0008 \\
(0.0017)\end{array}$ & & & $\begin{array}{l}-0.0016 \\
(0.0017)\end{array}$ & $\begin{array}{c}0.0004 \\
(0.0018)\end{array}$ & & \\
\hline Orphan $\%$ of Rxs & & & $\begin{array}{c}0.3095 \\
(0.1065)^{* *}\end{array}$ & $\begin{array}{c}0.1692 \\
(0.1094)\end{array}$ & $\begin{array}{c}0.3247 \\
(0.1078)^{* *}\end{array}$ & $\begin{array}{c}0.1637 \\
(0.1124)\end{array}$ & & $\begin{array}{c}0.2534 \\
(0.1085)^{*}\end{array}$ \\
\hline Prevalence Quintile 2 & & & & & & & $\begin{array}{l}-0.0487 \\
(0.0769)\end{array}$ & $\begin{array}{l}-0.0538 \\
(0.0765)\end{array}$ \\
\hline Quintile 3 & & & & & & & $\begin{array}{c}-0.0004 \\
(0.0720)\end{array}$ & $\begin{array}{l}-0.0019 \\
(0.0717)\end{array}$ \\
\hline Quintile 4 & & & & & & & $\begin{array}{l}-0.0417 \\
(0.0703)\end{array}$ & $\begin{array}{l}-0.0418 \\
(0.0700)\end{array}$ \\
\hline Quintile 5 & & & & & & & $\begin{array}{c}-0.0664 \\
(0.0693)\end{array}$ & $\begin{array}{l}-0.0613 \\
(0.0690)\end{array}$ \\
\hline Constant & $\begin{array}{c}0.2712 \\
(0.0504)^{* *}\end{array}$ & $\begin{array}{c}0.0117 \\
(0.0156)\end{array}$ & $\begin{array}{c}0.0047 \\
(0.0069)\end{array}$ & $\begin{array}{c}0.2398 \\
(0.0543)^{* *}\end{array}$ & $\begin{array}{c}-0.0097 \\
(0.0171)\end{array}$ & $\begin{array}{c}0.2464 \\
(0.0624)^{* *}\end{array}$ & $\begin{array}{c}0.0769 \\
(0.0690)\end{array}$ & $\begin{array}{c}0.0619 \\
(0.0690)\end{array}$ \\
\hline Observations & 479 & 479 & 479 & 479 & 479 & 479 & 479 & 479 \\
\hline R-squared & 0.05 & 0.00 & 0.02 & 0.06 & 0.02 & 0.04 & 0.01 & 0.03 \\
\hline
\end{tabular}

Notes: Standard errors in parentheses. * significant at 5\%; ** significant at 1\%. All regressions weighted by 1998 MD visits. 
Table 4: Mean Drugs Consumed and Prevalence

\begin{tabular}{|c|c|c|c|c|c|c|}
\hline & (1) & (2) & (3) & (4) & (5) & (6) \\
\hline & Mean \# Rx Pre & Mean \# Rx Pre & Mean \# Rx Pre & Mean \# Rx Post & Mean \# Rx Post & Mean \# Rx Post \\
\hline Log MD Visits (pre) & $\begin{array}{c}0.1390 \\
(0.0177)^{* *}\end{array}$ & & $\begin{array}{c}0.1138 \\
(0.0155)^{* *}\end{array}$ & & & \\
\hline Log Deaths '79 & & $\begin{array}{c}0.1034 \\
(0.0079)^{* *}\end{array}$ & $\begin{array}{c}0.0798 \\
(0.0077)^{* *}\end{array}$ & & & \\
\hline Log MD Visits (post) & & & & $\begin{array}{c}0.1502 \\
(0.0201)^{* *}\end{array}$ & & $\begin{array}{c}0.0991 \\
(0.0163)^{* *}\end{array}$ \\
\hline Log Deaths '98 & & & & & $\begin{array}{c}0.1248 \\
(0.0072)^{* *}\end{array}$ & $\begin{array}{c}0.1167 \\
(0.0071)^{* *}\end{array}$ \\
\hline Constant & $\begin{array}{c}-0.6560 \\
(0.2628)^{*}\end{array}$ & $\begin{array}{c}2.2681 \\
(0.0702)^{* *}\end{array}$ & $\begin{array}{c}0.3959 \\
(0.2502)\end{array}$ & $\begin{array}{c}-0.6139 \\
(0.3051)^{*}\end{array}$ & $\begin{array}{c}2.6730 \\
(0.0625)^{* *}\end{array}$ & $\begin{array}{c}1.1090 \\
(0.2646)^{* *}\end{array}$ \\
\hline Observations & 479 & 479 & 479 & 479 & 479 & 479 \\
\hline R-squared & 0.11 & 0.26 & 0.30 & 0.10 & 0.39 & 0.43 \\
\hline
\end{tabular}

Notes: Standard errors in parentheses. * significant at 5\%; ** significant at 1\%. All regressions weighted by contemporaneous MD visits. 
Table 5: Change in Mean Drugs, Prevalance, and Orphan Drug Use

\begin{tabular}{|c|c|c|c|c|c|c|c|c|}
\hline & (1) & (2) & (3) & (4) & (5) & (6) & (7) & (8) \\
\hline & $\begin{array}{l}\text { Change in } \\
\text { Mean \# Rx }\end{array}$ & $\begin{array}{l}\text { Change in } \\
\text { Mean \# Rx }\end{array}$ & $\begin{array}{l}\text { Change in } \\
\text { Mean \# Rx }\end{array}$ & $\begin{array}{l}\text { Change in } \\
\text { Mean \# Rx }\end{array}$ & $\begin{array}{l}\text { Change in } \\
\text { Mean \# Rx }\end{array}$ & $\begin{array}{l}\text { Change in } \\
\text { Mean \# Rx }\end{array}$ & $\begin{array}{l}\text { Change in } \\
\text { Mean \# Rx }\end{array}$ & $\begin{array}{l}\text { Change in } \\
\text { Mean \# Rx }\end{array}$ \\
\hline Log MD Visits (pre) & $\begin{array}{l}-0.0160 \\
(0.0115)\end{array}$ & & & $\begin{array}{l}-0.0062 \\
(0.0120)\end{array}$ & & $\begin{array}{c}-0.0286 \\
(0.0118)^{*}\end{array}$ & & \\
\hline Log Deaths '79 & & $\begin{array}{c}0.0371 \\
(0.0055)^{* *}\end{array}$ & & & $\begin{array}{c}0.0371 \\
(0.0055)^{* *}\end{array}$ & $\begin{array}{c}0.0407 \\
(0.0056)^{* *}\end{array}$ & & \\
\hline Orphan $\%$ of Rxs & & $\begin{array}{c}0.7250 \\
(0.3379)^{*}\end{array}$ & $\begin{array}{c}1.0773 \\
(0.3493)^{* *}\end{array}$ & $\begin{array}{c}1.0218 \\
(0.3658)^{* *}\end{array}$ & $\begin{array}{c}0.7250 \\
(0.3379)^{*}\end{array}$ & $\begin{array}{c}0.4340 \\
(0.3570)\end{array}$ & & $\begin{array}{c}1.0772 \\
(0.3587)^{* *}\end{array}$ \\
\hline Prevalence Quintile 2 & & & & & & & $\begin{array}{l}-0.1216 \\
(0.2550)\end{array}$ & $\begin{array}{l}-0.1434 \\
(0.2530)\end{array}$ \\
\hline Quintile 3 & & & & & & & $\begin{array}{l}-0.0810 \\
(0.2389)\end{array}$ & $\begin{array}{c}-0.0873 \\
(0.2369)\end{array}$ \\
\hline Quintile 4 & & & & & & & $\begin{array}{l}-0.1962 \\
(0.2333)\end{array}$ & $\begin{array}{c}-0.1967 \\
(0.2314)\end{array}$ \\
\hline Quintile 5 & & & & & & & $\begin{array}{l}-0.1726 \\
(0.2298)\end{array}$ & $\begin{array}{l}-0.1512 \\
(0.2280)\end{array}$ \\
\hline Constant & $\begin{array}{c}0.5102 \\
(0.1697)^{* *}\end{array}$ & $\begin{array}{c}0.5601 \\
(0.0535)^{* *}\end{array}$ & $\begin{array}{c}0.2277 \\
(0.0225)^{* *}\end{array}$ & $\begin{array}{c}0.3206 \\
(0.1817)\end{array}$ & $\begin{array}{c}0.5601 \\
(0.0535)^{* *}\end{array}$ & $\begin{array}{c}1.0227 \\
(0.1981) * *\end{array}$ & $\begin{array}{c}0.4441 \\
(0.2290)\end{array}$ & $\begin{array}{c}0.3804 \\
(0.2281)\end{array}$ \\
\hline $\begin{array}{l}\text { Observations } \\
\text { R-squared }\end{array}$ & $\begin{array}{l}479 \\
0.00\end{array}$ & $\begin{array}{l}479 \\
0.11\end{array}$ & $\begin{array}{l}479 \\
0.02\end{array}$ & $\begin{array}{l}479 \\
0.02\end{array}$ & $\begin{array}{l}479 \\
0.11\end{array}$ & $\begin{array}{l}479 \\
0.12\end{array}$ & $\begin{array}{l}479 \\
0.01\end{array}$ & $\begin{array}{l}479 \\
0.02\end{array}$ \\
\hline
\end{tabular}

Notes: Standard errors in parentheses. * significant at 5\%; ** significant at 1\%. All regressions weighted by 1998 MD visits in the condition. 
Table 6: Percent Dying Young and Prevalence

\begin{tabular}{|c|c|c|c|c|c|c|}
\hline & (1) & (2) & (3) & (4) & (5) & (6) \\
\hline & \% Dying Young, '79 & \% Dying Young, '79 & \% Dying Young, '79 & \% Dying Young, '98 & \% Dying Young, '98 & \% Dying Young, '98 \\
\hline Log MD Visits (pre) & $\begin{array}{c}-0.0324 \\
(0.0037)^{* *}\end{array}$ & & $\begin{array}{c}-0.0143 \\
(0.0043)^{* *}\end{array}$ & & & \\
\hline Log Deaths '79 & & $\begin{array}{c}-0.0353 \\
(0.0032)^{* *}\end{array}$ & $\begin{array}{c}-0.0278 \\
(0.0039)^{* *}\end{array}$ & & & \\
\hline $\begin{array}{l}\text { Log MD Visits } \\
\text { (post) }\end{array}$ & & & & -0.0218 & & -0.0069 \\
\hline Log Deaths '98 & & & & $(0.0032)^{* *}$ & $\begin{array}{c}-0.0339 \\
(0.0031)^{* *}\end{array}$ & $\begin{array}{c}(0.0035)^{*} \\
-0.0301 \\
(0.0037)^{* *}\end{array}$ \\
\hline Constant & $\begin{array}{c}0.5601 \\
(0.0497)^{* *}\end{array}$ & $\begin{array}{c}0.0116 \\
(0.0119)\end{array}$ & $\begin{array}{c}0.2270 \\
(0.0665)^{* *}\end{array}$ & $\begin{array}{c}0.4017 \\
(0.0432)^{* *}\end{array}$ & $\begin{array}{l}-0.0058 \\
(0.0115)\end{array}$ & $\begin{array}{c}0.1003 \\
(0.0547)\end{array}$ \\
\hline $\begin{array}{l}\text { Observations } \\
\text { R-squared }\end{array}$ & $\begin{array}{l}479 \\
0.14\end{array}$ & $\begin{array}{r}479 \\
0.20\end{array}$ & $\begin{array}{l}479 \\
0.22\end{array}$ & $\begin{array}{r}479 \\
0.09\end{array}$ & $\begin{array}{l}479 \\
0.20\end{array}$ & $\begin{array}{r}479 \\
0.20\end{array}$ \\
\hline
\end{tabular}

Notes: Standard errors in parentheses. * significant at 5\%; ** significant at $1 \%$. All regressions weighted by contemporaneous deaths in the condition. 
Table 7: Change in Percent Dying Young, Prevalence, and Orphan Drug Consumption

\begin{tabular}{|c|c|c|c|c|c|c|c|c|}
\hline & (1) & (2) & (3) & (4) & (5) & (6) & (7) & (8) \\
\hline & $\begin{array}{l}\text { Change in \% } \\
\text { Dying Young }\end{array}$ & $\begin{array}{l}\text { Change in \% } \\
\text { Dying Young }\end{array}$ & $\begin{array}{l}\text { Change in \% } \\
\text { Dying Young }\end{array}$ & $\begin{array}{l}\text { Change in \% } \\
\text { Dying Young }\end{array}$ & $\begin{array}{l}\text { Change in \% } \\
\text { Dying Young }\end{array}$ & $\begin{array}{l}\text { Change in \% } \\
\text { Dying Young }\end{array}$ & $\begin{array}{l}\text { Change in \% } \\
\text { Dying Young }\end{array}$ & $\begin{array}{l}\text { Change in \% } \\
\text { Dying Young }\end{array}$ \\
\hline Log MD Visits (pre) & $\begin{array}{c}0.0068 \\
(0.0013)^{* *}\end{array}$ & & $\begin{array}{c}0.0067 \\
(0.0013)^{* *}\end{array}$ & & $\begin{array}{c}0.0030 \\
(0.0015)^{*}\end{array}$ & $\begin{array}{c}0.0029 \\
(0.0015)\end{array}$ & & \\
\hline Log Deaths '79 & & $\begin{array}{c}0.0078 \\
(0.0011)^{* *}\end{array}$ & & $\begin{array}{c}0.0078 \\
(0.0011)^{* *}\end{array}$ & $\begin{array}{c}0.0063 \\
(0.0014)^{* *}\end{array}$ & $\begin{array}{c}0.0063 \\
(0.0014)^{* *}\end{array}$ & & \\
\hline Orphan \% of Rxs & & & $\begin{array}{c}-0.0782 \\
(0.0373)^{*}\end{array}$ & $\begin{array}{c}-0.0824 \\
(0.0366)^{*}\end{array}$ & & $\begin{array}{c}-0.0793 \\
(0.0365)^{*}\end{array}$ & & $\begin{array}{l}-0.0515 \\
(0.0376)\end{array}$ \\
\hline Prevalence Quintile 2 & & & & & & & $\begin{array}{c}0.0081 \\
(0.0113)\end{array}$ & $\begin{array}{c}0.0098 \\
(0.0113)\end{array}$ \\
\hline Quintile 3 & & & & & & & $\begin{array}{c}-0.0228 \\
(0.0105)^{*}\end{array}$ & $\begin{array}{r}-0.0197 \\
(0.0107)\end{array}$ \\
\hline Quintile 4 & & & & & & & $\begin{array}{c}0.0114 \\
(0.0094)\end{array}$ & $\begin{array}{c}0.0135 \\
(0.0095)\end{array}$ \\
\hline Quintile 5 & & & & & & & $\begin{array}{c}0.0256 \\
(0.0094)^{* *}\end{array}$ & $\begin{array}{c}0.0270 \\
(0.0094)^{* *}\end{array}$ \\
\hline Constant & $\begin{array}{c}-0.1152 \\
(0.0170)^{* *}\end{array}$ & $\begin{array}{c}0.0051 \\
(0.0047)\end{array}$ & $\begin{array}{c}-0.1076 \\
(0.0173)^{* *}\end{array}$ & $\begin{array}{c}0.0110 \\
(0.0054)^{*}\end{array}$ & $\begin{array}{l}-0.0409 \\
(0.0232)\end{array}$ & $\begin{array}{l}-0.0330 \\
(0.0234)\end{array}$ & $\begin{array}{c}-0.0351 \\
(0.0087)^{* *}\end{array}$ & $\begin{array}{c}-0.0330 \\
(0.0089)^{* *}\end{array}$ \\
\hline Observations & 479 & 479 & 479 & 479 & 479 & 479 & 479 & 479 \\
\hline R-squared & 0.06 & 0.09 & 0.07 & 0.10 & 0.10 & 0.11 & 0.10 & 0.11 \\
\hline
\end{tabular}

Notes: Standard errors in parentheses. * significant at 5\%; ** significant at $1 \%$. All regressions weighted by the 1998 deaths in the condition. 


\section{Appendix Table 1}

\section{Drugs that have been granted Orphan Drug Status by the FDA}

\begin{tabular}{|c|c|c|}
\hline Albendazole & Etanercept & Naltrexone Hydrochloride \\
\hline Aldesleukin & Ethanolamine Oleate & Nitric Oxide \\
\hline Alglucerase & Etidronate Disodium & Octreotide Acetate \\
\hline Alitretinoin & Exemestane & Ofloxacin \\
\hline Allopurinol & Factor IX (Human) & Oprelvekin \\
\hline Altretamine & Felbamate & Paclitaxel \\
\hline Amifostine & Filgrastim & Pegademase Bovine \\
\hline Aminosalicylic Acid & Fludarabine Phosphate & Pegaspargase \\
\hline Amiodarone Hydrochloride & Follitropin Alfa & Pentamidine Isethionate \\
\hline Amphotericin B & Fomepizole & Pentastarch \\
\hline Amphotericin B Lipid Complex & Fosphenytoin Sodium & Pentosan Polysulfate Sodium \\
\hline Anagrelide Hydrochloride & Ganciclovir Sodium & Pentostatin \\
\hline Antihemophilic Factor (Recombinant) & Gemtuzumab Ozogamicin & Pilocarpine \\
\hline Antithrombin III (Human) & Glatiramer Acetate & Poractant Alfa \\
\hline Aprotinin Bovine & Gonadorelin Acetate & Porfimer Sodium \\
\hline Atovaquone & Halofantrine Hydrochloride & Potassium Citrate \\
\hline Baclofen & Hemin & Proteinase Inhibitor (Human), Alpha 1 \\
\hline Basiliximab & Histrelin Acetate & Respiratory Syncytial Virus Immune Globulin \\
\hline Beractant & Hydroxyurea & Rho (D) Immune Globulin \\
\hline Betaine, Anhydrous & Idarubicin Hydrochloride & Rifabutin \\
\hline Bexarotene & Ifosfamide & Rifampin \\
\hline Bleomycin Sulfate & Imiglucerase & Rifapentine \\
\hline Botulinum Toxin & Immune Globulin (Human) & Riluzole \\
\hline Busulfan & Infliximab & Rituximab \\
\hline Caffeine Citrate & Interferon Alfa-2a, Recombinant & Sacrosidase \\
\hline Calcium Acetate & Interferon Alfa-2b, Recombinant & Sargramostim \\
\hline Calfactant & Interferon beta-1a & Satumomab Pendetide \\
\hline $\begin{array}{l}\text { Cetyl Alcohol; Colfosceril Palmitate; } \\
\text { Tyloxapol }\end{array}$ & Interferon Beta- $1 \mathrm{~b}$, Recombinant & Selegiline Hydrochloride \\
\hline Chenodiol & Interferon Gamma-1b, Recombinant & Sermorelin Acetate \\
\hline $\begin{array}{l}\text { Citric Acid; Glucono-Delta-Lactone; } \\
\text { Magnesium Carbonate }\end{array}$ & Iobenguane Sulfate I 131 & Sodium Benzoate; Sodium Phenylacetate \\
\hline Cladribine & Isoniazid; Pyrazinamide; Rifampin & Somatrem \\
\hline Clofazimine & Lamotrigine & Somatropin, Biosynthetic \\
\hline
\end{tabular}




\begin{tabular}{|c|c|c|}
\hline Clonidine Hydrochloride & Lepirudin (rDNA) & Sotalol Hydrochloride \\
\hline Coagulation Factor VIIa (Recombinant) & Leucovorin Calcium & Succimer \\
\hline Corticorelin Ovine Triflutate & Leuprolide Acetate & Sulfadiazine \\
\hline Cromolyn Sodium & Levocarnitine & Temozolomide \\
\hline Cysteamine Bitartrate & $\begin{array}{l}\text { Levomethadyl Acetate } \\
\text { Hydrochloride }\end{array}$ & Teniposide \\
\hline Cytarabine Liposome & Lidocaine & Teriparatide Acetate \\
\hline Cytomegalovirus Immune Globulin & Liothyronine Sodium & Thalidomide \\
\hline Daclizumab & Lodoxamide Tromethamine & Thyrotropin \\
\hline Daunorubicin Citrate Liposome & Mafenide Acetate & Tiopronin \\
\hline Denileukin Diftitox & Mefloquine Hydrochloride & Tobramycin \\
\hline Desmopressin Acetate & Megestrol Acetate & Toremifene Citrate \\
\hline Dexrazoxane Hydrochloride & Melphalan & Tretinoin \\
\hline Diazepam & Mesna & Trientine Hydrochloride \\
\hline Digoxin Immune Fab (Ovine) & Methotrexate Sodium & Trimetrexate Glucuronate \\
\hline Dornase Alfa & Metronidazole & Urofollitropin \\
\hline Doxorubicin, Liposomal & Midodrine Hydrochloride & Ursodiol \\
\hline Dronabinol & Mitoxantrone Hydrochloride & Valrubicin \\
\hline Eflornithine Hydrochloride & Modafinil & Zalcitabine \\
\hline Epirubicin Hydrochloride & Monoctanoin & Zidovudine \\
\hline Epoetin Alfa & Morphine Sulfate & Zinc Acetate \\
\hline Epoprostenol Sodium & Nafarelin Acetate & \\
\hline
\end{tabular}

\section{Source: Mosby's Drug Consult}

